\title{
A case of persistent left superior vena cava with absent right superior vena cava draining into dilated coronary sinus: magnetic resonance imaging and computed tomography findings
}

T Batinić ${ }^{*}$, Z Jurišić ${ }^{2}$, I Štula

From 23rd World Congress of the World Society of Cardio-Thoracic Surgeons

Split, Croatia. 12-15 September 2013

\section{Background}

We report a case of a persistent left superior vena cava (PLSVC) with absent right superior vena cava (RSVC). It is a very rare congenital anomaly also known as isolated PLSVC.

This venous malformation was identified in a 75 -yearold woman during cardiac magnetic resonance imaging (MRI), which was performed with the suspicion of a paracardiac mass.

\section{Methods}

We performed an MRI and a multislice computed tomography (MSCT) evaluation.

\section{Results}

Cardiac MRI revealed a persistent left superior vena cava which descended on the left side of the mediastinum and drained into the right atrium (RA) via a markedly dilated coronary sinus (CS) which mimicked a paracardiac mass. The RSVC was absent.

These findings were confirmed by MR and MSCT venography.

The patient had no additional cardiac abnormality.

\section{Conclusions}

Although PLSVC is usually asymptomatic, it is important to be aware of its existence, since it may cause problems performing central venous catheterization, pacemaker implantation and cardiothoracic surgery.

* Correspondence: Tonci.Batinic@xnet.hr

'Department of Radiology, University Hospital Split, Split, Croatia

Full list of author information is available at the end of the article
This anomaly is also associated with high incidence of congenital heart disease, arrhytmias and conduction disturbances.

Modern imaging techniques including computed tomography and magnetic resonance imaging provide precise diagnosis of this anomaly.

\section{Authors' details}

${ }^{1}$ Department of Radiology, University Hospital Split, Split, Croatia. ${ }^{2}$ Department of Cardiology, University Hospital Split, Split, Croatia.

Published: 11 September 2013

doi:10.1186/1749-8090-8-S1-067

Cite this article as: Batinić et al:: A case of persistent left superior vena cava with absent right superior vena cava draining into dilated coronary sinus: magnetic resonance imaging and computed tomography findings. Journal of Cardiothoracic Surgery 2013 8(Suppl 1): O67.

Submit your next manuscript to BioMed Central and take full advantage of:

- Convenient online submission

- Thorough peer review

- No space constraints or color figure charges

- Immediate publication on acceptance

- Inclusion in PubMed, CAS, Scopus and Google Scholar

- Research which is freely available for redistribution

Submit your manuscript at www.biomedcentral.com/submit 